\title{
RETINAL CHANGES ASSOCIATED WITH TAMOXIFEN TREATMENT FOR BREAST CANCER
}

\author{
ROSA TANG ${ }^{1}$, JERRY SHIELDS ${ }^{2}$, JADE SCHIFFMAN $^{1}$, HELEN LI $^{1}$, DIANA LOCHER ${ }^{1}$, \\ JAMES HAMPTON ${ }^{1}$, THOMAS PRAGER ${ }^{1}$ and GABRIEL PARDO ${ }^{1}$ \\ Galveston, Texas and Philadelphia, Pennsylvania
}

\begin{abstract}
SUMMARY
Purpose: This study was undertaken to estimate the incidence of retinal changes and determine the prevalence of ocular toxicity associated with tamoxifen treatment in a breast cancer population.

Methods: The study was based on a population crosssectional survey, including 290 patients taking tamoxIfen from 6 months to 12 years; 274 patients were analysed. The main outcome measures were the incidence of retinal changes and visual impairment.

Results: The incidence of retinal changes was $0.9 \%$ (3 of 274 patients). All 3 patients were asymptomatic. The length of tamoxifen treatment ranged from 39 months to 120 months in the affected patients, with cumulative tamoxifen doses ranging from $23.7 \mathrm{~g}$ to $73 \mathrm{~g}$.

Conclusions: Retinopathy in patients receiving low doses of tamoxifen is rare and, in our study, did not result in changes in visual acuity. We found no retinopathy in patients receiving tamoxifen within the first 3 years of treatment or in patients receiving a total tamoxifen dosage of less than 23.7 g. Although retinopathy can occur in a tamoxifen-treated population, its low incidence and an associated good prognosis for vision does not merit special screening for this problem.
\end{abstract}

Tamoxifen (Nolvadex), a non-steroidal oestrogen antagonist, has proved to be an effective adjuvant hormonal therapy in the treatment of breast cancer. ${ }^{1}$ This triphenylethylene derivative exerts its antioestrogenic properties by competitively binding to cytoplasmic oestrogen receptors, thus arresting the cell in $G_{1}$ phase.

From: ${ }^{1}$ Department of Ophthalmology, The University of Texas Medical Branch, Galveston, Texas; ${ }^{2}$ Oncology Service, Wills Eye Hospital, Philadelphia, Pennsylvania, USA.

Correspondence to: Rosa Ana Tang, MD, MPH, UTMB, Department of Ophthalmology, 2476 Bolsover \#359, Houston, Tx 77005, USA. Tel: +1 (713)-942-2182. Fax: +1 (713)-942-0265.
The ocular side effects of tamoxifen were first reported in 1978 by Kaiser-Kupfer and Lippman, ${ }^{2}$ who described white refractive retinal opacities and subepithelial opacities in the cornea in patients receiving high doses (up to $320 \mathrm{mg} / \mathrm{day}$ ) of the medication. In several subsequent studies, ${ }^{3-10}$ tamoxifen-induced ocular toxicity, including optic neuritis, was reported. Pavlidis et al. ${ }^{11}$ described similar toxicity in patients taking low doses of tamoxifen (20 mg/day); however, Beck and Mills ${ }^{12}$ and Longstaff $e t$ al. ${ }^{13}$ found no evidence of ocular side effects associated with the drug.

Tamoxifen is the most commonly prescribed agent for the treatment of breast cancer; and since major benefits are observed with treatment for 5 years or longer, it is important to evaluate the ocular toxicity associated with the chronic use of this drug. We present the results of ocular examinations in 290 breast cancer patients who received standard doses $(20 \mathrm{mg} /$ day $)$ of tamoxifen.

\section{PATIENTS AND METHODS}

A total of 290 patients receiving $20 \mathrm{mg} /$ day of tamoxifen had ocular examinations; records of the length of tamoxifen treatment were available for 274 patients. Patients were selected from three centres: 80 were recruited from the Ocular Oncology Service, Wills Eye Hospital, Philadelphia, PA (J.S.); 90 were from a private ophthalmology practice, Houston, TX (R.T.); and the remaining 120 patients were recruited from a private oncology practice, Oklahoma City, OK (J.H.). The mean age in the Oklahoma City group was 66 years, and the mean age in the Houston group was 58 years.

Criteria for enrolment in the study included diagnosis of breast cancer, treatment with tamoxifen, and agreement to an ophthalmological examination. Ophthalmic complaints were not a requirement for 
Table I. Treatment duration and results by groups

\begin{tabular}{lcccc}
\hline & No. of patients & $\begin{array}{c}\text { Duration of treatment (months) } \\
\text { Mean } \pm \text { SD }\end{array}$ & $\begin{array}{c}\text { Tamoxifen dosage (g) } \\
\text { Mean } \pm \text { SD }\end{array}$ & $\begin{array}{c}\text { Patients with } \\
\text { retinal changes }\end{array}$ \\
\hline Philadelphia & 73 & $18.42 \pm 17.42$ & $11.4 \pm 10.4$ & 0 \\
Houston & 81 & $22.11 \pm 20.47$ & $13.3 \pm 12.3$ & 0 \\
Oklahoma City & 120 & $55.29 \pm 38.0$ & $33.18 \pm 22.8$ & 3 \\
Total & 274 & $35.66 \pm 33.80$ & $21.4 \pm 20.28$ & 3 \\
\hline
\end{tabular}

inclusion; neither was there a specified length of tamoxifen treatment.

Eye examinations were concentrated on the fundus. The examination comprised the following: visual acuity, Amsler grid testing, applanation tonometry and full dilated funduscopic examination with both the direct and indirect ophthalmoscope. Fundus photography documented all retinal pathology.

\section{RESULTS}

Crystalline deposits in the posterior pole consistent with previously described tamoxifen retinopathy were found in 3 patients $(0.9 \%)$ (Table I). No other ocular abnormalities were evident, and visual acuity was not affected in any of the 3 patients. The length of tamoxifen treatment in these 3 patients ranged from 39 months to 120 months, and the total dosage of tamoxifen ranged from $23.7 \mathrm{~g}$ to $73 \mathrm{~g}$ (Table II). All 3 patients with retinal changes were found in the Oklahoma City group, which had the longest mean duration of treatment (55 months) and the highest total dosage of tamoxifen (72 g).

\section{DISCUSSION}

Tamoxifen has proved to be beneficial in the treatment of advanced breast cancer. In recent years there have been reports indicating its beneficial effects in the early stages of breast cancer as well. Recently, the Early Breast Cancer Trialists' Collaborative Group reported the results of a metaanalysis involving more than 30000 patients in 40 clinical trials in which tamoxifen therapy was used in the early stages of breast cancer. ${ }^{14}$ A significant survival and disease-free interval was shown in tamoxifen-treated patients versus controls. The standard practice is to treat breast cancer patients for 5 years or longer. ${ }^{14}$ In this report, greater benefit was observed with a longer duration of therapy.

Tamoxifen is remarkably well tolerated, with fewer than $3 \%$ of patients withdrawing from clinical trials. Although most of the toxicity is related to the anti-oestrogenic properties of the drug, ocular toxicity has also been reported - specifically a tamoxifen-induced retinopathy.

A review of tamoxifen-induced retinopathy reported in the literature is shown in Table III. Retinopathy is a rare occurrence in patients receiving $20 \mathrm{mg}$ daily of tamoxifen; in our study it was not associated with changes in visual acuity or visual function. We found no evidence of tamoxifen retinopathy during the first 3 years of treatment or with a total dosage of less than $23.7 \mathrm{~g}$. Some patients treated with higher doses (180 mg or more daily) have been found to develop a reversible crystalline maculopathy and, occasionally, a keratopathy. ${ }^{2}$ The clinical significance of these crystalline deposits in the retina is unknown. Although they have been found in the outer plexiform layer, ${ }^{3}$ their exact location is still a matter of debate. Given the chemical composition of tamoxifen and its structural similarity to other toxic ocular agents with cationic, amphophilic properties such as chloroquine, amiodarone and phenothiazine, ${ }^{16}$ tamoxifen may be expected to accumulate as a drug-lipid complex in the lysosomes of the cornea and retina - most probably at the level of the retinal pigment epithelium. This chemical similarity lets us also speculate that its toxicity may be dose related rather than idiosyncratic. A cumulative dosage effect is also supported by the fact that we found no abnormalities in patients taking a total dosage of less than $23.7 \mathrm{~g}$, which is equivalent to 3 years of treatment.

Patients who have visual complaints while undergoing tamoxifen therapy should see their ophthalmologist for evaluation. Together, the ophthalmologist and oncologist can best coordinate the continuation of treatment based on the visual complaint and ocular examination.

The clinical significance of retinal findings in the absence of visual changes remains unknown. The results of this study suggest that annual eye examinations during the first 3 years of treatment are unlikely to reveal retinal damage secondary to tamoxifen.

Table II. Clinical factors associated with retinal changes

\begin{tabular}{lcccc}
\hline Patient & $\begin{array}{c}\text { Age } \\
\text { (years) }\end{array}$ & $\begin{array}{c}\text { Total dosage of tamoxifen } \\
(\mathrm{g})\end{array}$ & $\begin{array}{c}\text { Duration of treatment } \\
\text { (months) }\end{array}$ & Visual acuity \\
\hline 1 & 69 & 23.7 & 39 & $20 / 20$ \\
2 & 56 & 73 & 120 & $20 / 20$ \\
3 & 73 & 73 & 120 & $20 / 20$ \\
\hline
\end{tabular}


Table III. Tamoxifen-induced retinopathy: review of the literature

\begin{tabular}{|c|c|c|c|c|c|c|}
\hline \multirow[b]{2}{*}{ Author/Year/Reference } & \multicolumn{2}{|c|}{ No. of patients } & \multicolumn{2}{|c|}{ Dosage of tamoxifen } & \multirow{2}{*}{$\begin{array}{l}\text { Duration } \\
\text { (months) }\end{array}$} & \multirow[b]{2}{*}{ Retinal changes } \\
\hline & Total & Retinopathy & Daily & Total & & \\
\hline Kaiser-Kupfer and Lippman, $1978^{2}$ & 4 & 4 & $240-320 \mathrm{mg}$ & $108-320 \mathrm{~g}$ & $17-27$ & $\begin{array}{l}\text { White refractile retinal opacities, } \\
\text { posterior pole. White, subepithelial } \\
\text { corneal opacities }\end{array}$ \\
\hline Beck and Mills, $1979^{12}$ & 19 & 0 & $40 \mathrm{mg}$ & - & $3-48$ & No retinal changes \\
\hline Kaiser-Kupfer et al., $1981^{3}$ & $1^{\mathrm{a}}$ & - & $40-240 \mathrm{mg}$ & - & 42 & $\begin{array}{l}\text { Superficial lesions overlying retinal } \\
\text { vessels. Post-mortem: lesions } \\
\text { confined to retinal nerve fibre and } \\
\text { inner plexiform layer }\end{array}$ \\
\hline McKeown et al., $1981^{4}$ & 1 & 1 & $180 \mathrm{mg}$ & $158 \mathrm{~g}$ & 30 & $\begin{array}{l}\text { Bilateral retinal opacities; cystoid } \\
\text { macular oedema }\end{array}$ \\
\hline Vinding and Nielsen, $1983^{5}$ & 17 & 2 & $20-30 \mathrm{mg}$ & $5.8-15 \mathrm{~g}$ & $7-25$ & $\begin{array}{l}\text { Yellowish-white opacities, posterior } \\
\text { pole of retina }{ }^{\mathrm{b}}\end{array}$ \\
\hline Pugesgaard et al., $1986^{6}$ & 1 & 1 & $30-40 \mathrm{mg}$ & $6 \mathrm{~g}$ & 6 & Bilateral optic neuritis \\
\hline Griffiths, $1987^{7}$ & 1 & 1 & $20 \mathrm{mg}$ & $7.7 \mathrm{~g}$ & 7 & $\begin{array}{l}\text { Decreased visual acuity; macular } \\
\text { oedema by fluorescein angiographyc }\end{array}$ \\
\hline Ashford et al., $1988^{8}$ & 1 & 1 & $20 \mathrm{mg}$ & $0.4 \mathrm{~g}$ & $3 \mathrm{wk}$ & $\begin{array}{l}\text { Bilateral optic disc swelling; retinal } \\
\text { haemorrhages }^{\mathrm{c}}\end{array}$ \\
\hline Longstaff et al., $1989^{13}$ & 79 & 0 & $20-60 \mathrm{mg}$ & $\begin{array}{l}24.3 \mathrm{~g} \\
(\text { mean })\end{array}$ & $\begin{array}{c}27 \\
(\text { mean })\end{array}$ & No retinal changes \\
\hline Gerner, $1989^{9}$ & 1 & 1 & $30-40 \mathrm{mg}$ & $22.8 \mathrm{~g}$ & 26 & $\begin{array}{l}\text { Refractile opacities, inner retinal } \\
\text { layer at paramacular area; bilateral } \\
\text { cystic macular changes }\end{array}$ \\
\hline Pavlidis et al., $1992^{11}$ & 63 & 4 & $20 \mathrm{mg}$ & $3.6-30 \mathrm{~g}$ & $6-51$ & $\begin{array}{l}\text { Decreased visual acuity; macular } \\
\text { oedema; yellow-white opacities in } \\
\text { paramacular and foveal areas. } \\
\text { Corneal opacities ( } 1 \text { patient })^{\mathrm{b}}\end{array}$ \\
\hline Chern and Davis, $1993^{10}$ & 1 & 1 & $20 \mathrm{mg}$ & - & 36 & $\begin{array}{l}\text { Refractile opacities, paramacular } \\
\text { area of left eye. Increase of deposits } \\
\text { at } 8 \text { months; macular changes in right } \\
\text { eye at } 13 \text { months }\end{array}$ \\
\hline Heier et al., $1994^{15}$ & 135 & 2 & $20 \mathrm{mg}$ & $\begin{array}{l}17.2 \mathrm{~g} \\
(\text { mean })\end{array}$ & $2-244$ & $\begin{array}{l}\text { Intraretinal refractile crystals; no } \\
\text { visual symptoms or visual loss, con- } \\
\text { tinued } 3 \text { month follow-up intervals }\end{array}$ \\
\hline
\end{tabular}

${ }^{\mathrm{a}}$ This patient was reported in the 1978 study.

${ }^{b}$ Retinal changes persisted after discontinuation of the drug.

${ }^{c}$ Retinal changes regressed after discontinuation of the drug.

${ }^{\mathrm{d}}$ Patient was lost to follow-up.

This work was supported in part by a grant from Zeneca Pharmaceutical Inc. and Research to Prevent Blindness.

Key words: Cancer, Breast, Retina, Tamoxifen.

\section{REFERENCES}

1. Fisher B, Constantino J, Redmond C, et al. A randomised clinical trial evaluating tamoxifen in the treatment of patients with node-negative breast cancer who have estrogen-receptor-positive tumors. N Engl J Med 1989;320:479-84.

2. Kaiser-Kupfer M, Lippman M. Tamoxifen retinopathy. Cancer Treat Rep 1978;62:315-20.

3. Kaiser-Kupfer M, Kupfer C, Rodrigues M. Tamoxifen retinopathy: a clinicopathologic report. Ophthalmology 1981;88:89-93.

4. McKeown C, Swartz M, Blom J, Maggiano J. Tamoxifen retinopathy. Br J Ophthalmol 1981;65:177-9.

5 . Vinding $T$, Nielsen N. Retinopathy caused by treatment with tamoxifen in low dosage. Acta Ophthalmolol (Copenh) 1983;61:45-50.

6. Pugesgaard T, Von Eyben F. Bilateral optic neuritis evolved during tamoxifen treatment. Cancer 1986;58: 383-6.

7. Griffiths M. Tamoxifen retinopathy at low dosage [letter]. Am J Ophthalmol 1987;104:185-6.

8. Ashford A, Donev I, Tiwari R, Garrett T. Reversible ocular toxicity related to tamoxifen therapy. Cancer 1988;61:33-5.
9. Gerner E. Ocular toxicity of tamoxifen. Ann Ophthalmol 1989;21:420-3.

10. Chern S, Danis R. Retinopathy associated with lowdose tamoxifen [letter]. Am J Ophthalmol 1993;116: 372-5.

11. Pavlidis N, Petris C, Briassoulis E, et al. Clear evidence that long-term, low-dose tamoxifen treatment can induce ocular toxicity: a prospective study of 63 patients. Cancer 1992;69:2961-4.

12. Beck M, Mills P. Ocular assessment of patients treated with tamoxifen. Cancer Treat Rep 1979;63:1833-4.

13. Longstaff S, Sigurdsson $\mathrm{H}$, O'Keeffe $\mathrm{M}$, et al. A controlled study of ocular effects of tamoxifen in conventional dosage in the treatment of breast carcinoma. Eur J Cancer Clin Oncol 1989;25:1805-8.

14. Early Breast Cancer Trialists' Collaborative Group. Systemic treatment of early breast cancer by hormonal, cytotoxic, or immune therapy. Lancet 1992;339: $71-85,115$

15. Heier J, Dragoo R, Enzenauer R, Waterhouse W. Screening for ocular toxicity in asymptomatic patients treated with tamoxifen. Am J Ophthalmol 1994;117: $772-5$.

16. Flach A. Clear evidence that long-term, low-dose tamoxifen treatment can induce ocular toxicity: a prospective study of 63 patients [comment]. Surv Ophthalmol 1994;38:392-3. 